\author{
Maria Groenwald \\ Uniwersytet Gdański \\ mgroenwald@rubikon.pl
}

\title{
Inspirujący Anton Makarenko. Z analizy hieroglifów na „Dziełach”
}

\section{Summary}

\section{Inspiring Anton Makarenko. From an analysis of hieroglyphs on "Works"}

In the paper "hieroglyphs" denotes (metaphorically) all meanings assigned by readers of texts comprising "Works" by A. Makarenko, thus designating highlighted fragments as meaningful. Their analysis has been directed at those issues that particularly appealed to the readers and the possibilities arising from them of applying knowledge to work with pupils. It turns out that while reading "Works" they focused on: (1) aims of upbringing and ways of fulfilling them: discipline, codes of conduct, collective group structure; (2) A. Makarenko himself, in whom they sought the ideal of a pedagogue. The analysis closes with a reflection on the role of the reader of "Works" as their peculiar translator who, through both reproductive and innovative work with the text (carried out through the prism of one's own knowledge, experience or needs), enters the path of translating-interpreting pedagogical activity.

Słowa kluczowe: Anton Makarenko, „Dzieła”, analiza hieroglifów

Keywords: Anton Makarenko, "Works", analysis of hieroglyphs

Twórczość Antona Makarenki określam jako inspirującą, gdyż w przeszłości jego prace cieszyły się sporym zainteresowaniem, również wśród polskich czytelników. Tezę o poczytności prac tego pedagoga wysuwam na podstawie obserwacji poczynionych podczas lektury „Dzieł”, zauważyłam bowiem, że niektóre fragmenty zostały w nich podkreślone, zakreślone lub opatrzone dopiskami, czyli - jak sądzę - uznane za bardziej istotne od innych. W związku z tym zaciekawiło mnie: Czego szukali oni w jego pracach, co w nich odnaleźli i jak mogli pozyskaną wiedzę zastosować w pracy z wychowankami? Niniejsze opracowanie jest zapisem poszukiwania odpowiedzi na to pytanie.

\section{O metodzie badań i analizie}

Swoje dociekania lokuję w obrębie badań jakościowych, gdyż skupiam uwagę na ograniczonej liczbie przypadków dobranych do sformułowanego wyżej celu (Demetrio 2009: 159). Zastosowaną metodą jest analiza tekstu (Peräkylä 2009), w tym przypadku - zakreśleń w „Dziełach” Makarenki, które nazwałam hieroglifami, przy czym tym określeniem nie nawiązuję do pisma egipskiego, ale do znaczenia nadawanego mu w geologii. Tam 
określa się nimi ślady pozostawione na mulistym lub piaszczystym podłożu przez poruszające się zwierzęta albo utworzone pod wpływem czynników mechanicznych, jako pozostałość po wleczeniu, uderzaniu, działaniu prądów. Kiedy wgłębienia zostają wypełnione materiałem skalnym, powstają wypukłe odlewy, które badaczom dostarczają danych o środowisku, o warunkach sedymentacji osadów i skał osadowych, w których one występują, oraz o kierunku transportu wleczonego materiału, a więc i o kierunkach prądów. Ponadto hieroglify są także pomocne w ustalaniu budowy geologicznej silnie sfałdowanych masywów górskich (Passendorfer 1968: 439-441; Słownik języka polskiego 2017). Podobnie jak w geologii, hieroglify na kartach książek Makarenki o czymś mówią, coś „usituja komunikować - przyciągają uwagę, stawiają znaki zapytania, łączą pasujące do siebie dyskursy opatrzone właściwymi kodami, dzięki którym «udostępniona» zostaje, przynajmniej w części, natura ich autora" (Demetrio 2009: 162). Pokazują nie tylko to, co przed laty było dla czytelników ważne, ale też stają się zwiastunami późniejszego rozwoju wydarzeń oraz zapowiedzią ich możliwego zakończenia (Demetrio 2009: 163). Nie podejmuję się w ich analizie poszukiwania przyczyn zaznaczenia określonych fragmentów tekstu. Dysponując jedynie pieczęciami bibliotek na „Dziełach” nie można wykluczyć, że zakreśleń dokonywali studenci lub nauczyciele przymuszeni do ich lektury. Jednak ten trop myślowy mieści się w sferze domniemań wykraczających poza cel stawiany niniejszemu opracowaniu, stąd dalsze podążanie nim uznaję za bezzasadne.

Stosując metaforę hieroglifu wpisuję się w analizę hermeneutyczną, ,za pomocą której możliwe jest opisywanie innobytu pewnej realności w odmiennym substracie. W rezultacie przekształcania się i integracji treści, dane wyjściowe ulegają transformacji: redukują się interakcje, rozpadają się ogniwa towarzyszące i zależności pośrednie, jedne cechy przedmiotów funkcjonalne $\mathrm{w}$ danej przekształconej formie, nabierają znaczenia, a inne zanikają" (Prokpiuk 2010: 127). Duccio Demetrio podkreśla, że język pisany - w tym przypadku hieroglify - odkrywają kontekst znaczeń i tworzą namacalne świadectwo istnienia (2009: 67). Ich czytanie wiąże się z podjęciem trudu metapoznania, dla którego właściwe są pytania o cele tego poznawania, metodę oraz przyjęte założenia, oraz wejście badacza w rolę „narzędzia badawczego" (Richardson, St. Pierre 2009: 458).

W analizie zakreśleń tekstów A. Makarenki sięgam po metaforę hieroglifu dlatego, że umożliwia ona:

- ujawnienie procesów pedagogicznych oraz ukazanie ich wieloaspektowości,

- włączenie refleksyjności do analizy rzeczywistości pedagogicznej,

- uwolnienie myślenia o zjawiskach i procesach pedagogicznych od stereotypów (Prokopiuk 2010: 127),

- „zrozumienie i doświadczenie pewnego rodzaju rzeczy w terminach innej rzeczy” (Lakoff 1988: 27),

- otwarcie dostępu do nowego rozumienia doświadczeń, wzbogacenie o nowe znaczenia wiedzy o codziennych działaniach (Lakoff 1988: 167),

- pozyskanie wiedzy o czytelnikach „Dzieł”: o ich potrzebach, ale i też o nich samych,

- poznanie „losów” analizowanych tomów. 
Jak już wspomniałam, zgodnie z przyjętą metaforą podłoże hieroglifów stanowią karty prac A. Makarenki, czyli te „Dzieła” wydane w latach pięćdziesiątych ubiegłego stulecia, które są zasobami Biblioteki Uniwersytetu Gdańskiego. Ze stawianych w nich pieczęci bibliotecznych, dodawanych w kolejnych latach, wyłania się historia wędrówki tomów przez instytucje oświatowe. Choć czasem zmieniały się tylko nazwy instytucji, tym niemniej pociągało to za sobą konieczność przypisania im „Dzieł” od nowa, a więc ponownego opieczętowania. Otóż pierwotnie stanowiły one zbiory Biblioteki Studium Doskonalenia Kadr Oświatowych w Sopocie, potem Biblioteki Studium Nauczycielskiego w Gdańsku, a następnie Biblioteki Uniwersytetu Gdańskiego, przekształconej obecnie w Bibliotekę Główną Uniwersytetu Gdańskiego. Prócz „Dzieł” sporym zainteresowaniem czytelników cieszyły się także książki: Ireneusza Pyrzyka „Prekursorzy pedagogiki opiekuńczej” (2002) oraz Mikołaja Fere „Mój nauczyciel A. Makarenko” (1954); świadczą o tym licznie zaznaczane fragmenty tekstu omawiającego prace Antona Makarenki. Dlatego postanowiłam te prace również uczynić przedmiotem analizy.

\section{Analiza hieroglifów na „Dziełach”}

Przypuszczam, że Anton Makarenko doświadczyłby rozczarowania, gdyby uświadomił sobie, że szereg jego doświadczeń wyniesionych z pracy z wychowankami oraz opisanych w „Dziełach”, nie znalazło uznania u czytelników, a interesujące ich wątki zostały ograniczone do zaledwie kilku zagadnień zawartych w trzech tomach, w których pozostawili ślady lektury. To kwestie: (1) celów wychowania; (2) sposobów ich osiągania.

\section{Cele wychowania}

Wzbudzające czytelnicze zainteresowanie cele wychowania przez A. Makarenkę były rozumiane jako ,program osobowości człowieka, (...) słowem absolutnie wszystko co składa się na (jego) obraz; (...) program (...), do którego realizacji my pedagodzy powinniśmy dążyć” (Makarenko 1950: 49). Jak dalej pisze: wychowanie czyli „projektowania osobowości, jako produktu wychowania, powinno się dokonywać na podstawie potrzeb społeczeństwa tak, by był dla klasy pracującej pożyteczny" (tamże). Zatem czytający prace Makarenki dowiaduje się, że poddawany oddziaływaniom wychowawczym młody człowiek powinien dopasować się do oczekiwań społecznych, wejść w zaplanowaną dla niego rolę, co wpisuje się w dobrze ugruntowane na gruncie polskiej edukacji tradycyjne podejście do wychowania (np. Śliwerski 2015, Kosiorek 2007). Równocześnie w tym samym tomie „Wybranych prac...” czytelnicy podkreślają, że celem tak rozumianego wychowania jest: zapewnienie dobrobytu wychowanka, jego potrzeb i zainteresowań (Makarenko 1950: 50).

Trudno w tym momencie stwierdzić, jaką wiedzę z lektury przywołanych powyżej dwu zaznaczonych fragmentów wyniosła czytająca je osoba. Być może - po pierwsze uznała, że potrzebą wychowanka jest być pożytecznym dla innych (dokładnie: dla klasy 
pracującej), a zaspokojenie tej potrzeby zapewni mu dobrobyt. Ale niewykluczone - po drugie - że wyniosła z nich przeświadczenie o dwoistości celów rozumianej, za Lechem Witkowskim (2013: 715) jako jeden z wielu przypadków nieuchronnych dylematów obecnych w pracy zawodowej, które skazują go na przyjmowanie postaw: alternującej bądź oscylującej, przy czym ta ostatnia może okazać się ogromnie wyczerpująca i dla wychowawcy, i dla wychowanka, wiąże się bowiem z brakiem jednoznacznego sensu pedagogicznej roboty oraz z niekończącą się niepewnością w ich wzajemnych relacjach.

Anton Makarenko w opisie celów wychowania (co również interesuje czytelników) wskazuje na ich zróżnicowanie wynikające z niejednakowego zasięgu i różnego czasu realizacji, co pozwala na wyłonienie perspektyw realizacji:

- bliskiej, która zaczyna się od planów osobistych,

- średniej, nieco oddalonej w czasie, jak na przykład planowanie wyjazdu na urlop, do uzdrowiska bądź zgłębienie jakichś wiadomości w bliżej nieokreślonej przyszłości,

- dalekiej, rozumianej jako powiązanie własnej przyszłości w z pomyślnością Związku Radzieckiego (Makarenko 1950: 134, 135).

Zwraca też uwagę (co zostaje w książce podkreślone) na konieczność „przechodzenia od bliższego do dalszego zaspokajania potrzeb, harmonizowania osobistych i zbiorowych perspektywy tak, żeby wychowanek nie miał wrażenia, że między nimi zachodzi sprzeczność" (Makarenko 1950: 131). W tym miejscu czytelnik mógłby odnieść wrażenie, że Makarenkowska koncepcja wykazuje spójność z podejściem Lwa Wygotskiego (1971; Filipiak 2011) i określonymi przez niego strefami rozwoju:

- aktualnego, z już posiadanymi: wiedzą, umiejętnościami, postawami przyjmowane w codzienności i wobec niej,

- najbliższego, nakierowanego na: potencjał rozwojowy wychowanka, obszary wymagające wsparcia, cechy otoczenia, w którym się uaktywnią lub rozwiną jego nowe kompetencje.

Jednak już dalsza lektura hieroglifów na „Dziełach” burzy przypuszczenie o zbieżności poglądów tych dwu pedagogów na cele głównie dlatego, że wskazywana przez Makarenkę droga ich osiągania - w przeciwieństwie do Wygotskiego - okazuje się skrajnie autorytarna.

\section{Drogi osiągania celów wychowania}

Czytelników „Dziel” interesuje nie tylko to, co w wychowaniu jest istotne, ale też jak dokonać tego, by cele własne były ukierunkowane na dobro państwa i aby w przeświadczeniu wychowanka tworzyły one jedność. Zdaniem Makarenki można tego dokonać dzięki wychowaniu przez wdrażanie do pracy opierającej się „na pojęciu wartości, które praca może wytwarzać" (Makarenko 1956: 191). Choć pedagog uważa, że owego wdrażania należy dokonywać na prośbę wychowawcy lub z jego nakazu, to jednak uwagę czytających „Dzieła” przyciągają wyłącznie kwestie dyscypliny, czyli: czym ona jest, oraz jak w jej utrzymaniu pomagają regulamin oraz kolektyw, w którym szczególna rola przypada wychowawcy. 


\section{Rozumienie dyscypliny}

Osoby zainteresowane metodami wychowawczymi polecanymi przez A. Makarenkę wyróżniają swoiste rozumienie przez niego dyscypliny, którą określa jako kategorię moralną. Jak pisze: „Dyscyplina nie dotyczy kwestii posłuszeństwa, podporządkowania się, uległości, mechanicznego wykonywania obowiązujących rygorów czy regulaminów. Dyscyplina jest kategorią nie tyle porządkową, ile raczej na wskroś etyczną" (Makarenko 1956: 37; Pyrzyk 2002: 112). Tym samym postawom wychowanków wobec wychowawców, polegających na: podporządkowaniu, posłuszeństwie i przestrzeganiu reguł stanowionych przez innych, nadaje on znaczenie postępowania wartościowego oraz moralnie słusznego. Czytelnicy jednak zdają się nie dostrzegać tego manipulowania wartościami i nazywania „zachowaniem dobrym moralnie” takiego, które jest uwewnętrznionym posłuszeństwem wychowawcom i regulaminom.

Zarówno w określaniu celów wychowania, jak i w definiowaniu dyscypliny, Makarenko wprowadza wykluczające się znaczenia i buduje konstrukty wewnętrznie sprzeczne. $\mathrm{Z}$ jednej bowiem strony przekonuje, że dyscyplina jest kategorią etyczną, ponieważ jest budowana na fundamencie odpowiedzialnej postawy wobec potrzeb innych ludzi. Zarazem z drugiej powiada, że dyscyplinę można realizować poprzez wymagania i autorytet wychowawców, a szczególnie przez regulamin (Pyrzyk 2002: 109). Dla czytelników oznacza to, że przestrzeganie regulaminu jest moralnie dobre i etyczne. Łamanie go - złe moralnie i zasługujące na karę.

\section{Rola regulaminu}

Regulamin był ważnym dokumentem nie tylko dla A. Makarenki, ale - jak wynika z analizy jego prac - znaczącym także dla czytających „Dzieła”, gdyż zakreślili fragmenty tekstu, z których wynika, że ów regulamin:

- stanowi najważniejsze kryterium osądu i rozstrzyga o tym, co moralnie dobre a co złe,

- zdejmuje z wychowawców odpowiedzialność za kary nakładane na wychowanków,

- nadaje wychowawcom szczególne uprawnienia do zarządzania najdrobniejszymi szczegółami dotyczącymi wychowanków, np. mają systematycznie kontrolować ubiór podopiecznych i dbałość o jego stan, sprawdzać czy nie zakładają czapek odzieży regulaminowo zakazanej, gdyż ich noszenie „przyzwyczaja wychowanków do niepotrzebnego opatulania się" (Makarenko 1956: 52-56).

Tak oto w „Dziełach” czytelnik znajdował przyzwolenie dla wszechwładzy nauczyciela nad wychowankiem. Nie dziwi zatem, że funkcja regulaminu jako narzędzia pomocnego w utrzymaniu dyscypliny go zaciekawiła. Choć niewykluczone, że bliskie było mu i inne rozumienie dyscypliny, jako sposobu okazywania swojej miłości do dziecka, albo wyrażania poszanowania jego godności, bądź instrumentu zdolnego nakłonić je do pożądanych zachowań bez stosowania przemocy fizycznej lub psychicznej (Foucault 2009; Mieszalski 1997). 


\section{Struktura kolektywu}

Oprócz regulaminu, drugim „narzędziem” sprzyjającym utrzymaniu dyscypliny jest kolektyw. Czytający „Dzieła” skrupulatnie zaznaczają, że składa się on z oddziałów liczących 7-15 osób w różnym wieku, uczęszczających do różnych klas w szkole. Ale tym, co je jednoczy są:

- rytm codziennego życia toczony według ustalonych form i porządku,

- wspólne miejsce pracy,

- wspólnie zajmowane miejsce w jadalni i sypialni,

- wspólne uczenie się, podczas którego starsi wychowankowie pomagają młodszym (Makarenko 1956: 7, 10; Makarenko 1955: 577).

Czytelnicy wyróżniają ponadto w tekście, że relacje w obrębie kolektywu cechuje hierarchia. Zgodnie z nią najniższą pozycję zajmuje wychowanek - kandydat, ale już pewne przywileje zostają nadane komunardom - członkom komuny, którzy z kolei podlegają wychowawcy klasy oraz dowódcy oddziału (i zastępcy dowódcy oddziału). Jeszcze wyżej jest usytuowany kierownik pedagogiczny (Makarenko 1950: 78). Zwraca uwagę nadanie w komunie wysokiego statusu wychowawcy, o czym świadczą posiadane przez niego uprawnienia umożliwiające mu realizację spoczywających na nim zadań. Jednym z nich jest obowiązkowo prowadzony dzienniczek, w którym opisuje:

- stosunek każdego wychowanka do zakładu, czy go ceni, czy jest mu obojętny, wrogi,

- stosunek do pracy, zwłaszcza czy nie jest on nacechowany tylko dzisiejszą perspektywą bez poczucia jutra,

- stosunek do innych wychowanków (kogo lubi, z kim się przyjaźni) i do dowódcy oddziału,

- co czyta: jaką literaturę, książki, gazety,

- jakie wykazuje uzdolnienia i talenty, które należałoby w nim rozwijać,

- jaki jest stan materialny domu rodzinnego wychowanka, jakie są zarobki wychowanka, czy pomaga rodzinie, oszczędza, pomaga kolegom (Makarenko 1950: 131).

Jednak ów dzienniczek pełni rolę miecza obosiecznego; z jednej strony prowadzone w nim szczegółowe zapiski dotyczą wychowanków i wtedy jest on narzędziem pracy wychowawcy, uprawniającym go do inwigilacji podopiecznych, sprawowania nad nimi władzy, do ich nadzorowania i karania. Zarazem z drugiej strony, na wychowawcy spoczywa przymus sporządzania owych notatek, a ich brak lub pobieżność mogą świadczyć o braku odpowiednich kompetencji pedagogicznych, niewłaściwej postawie ideologicznej, bądź o nieczystych intencjach wobec wychowanka lub zwierzchnika, czyli kierownika pedagogicznego.

Dla czytelników okazuje się ważne, że to właśnie kierownik zajmuje centralną pozycję w komunie, jest w jej sercu i sam tym sercem jest. „Dzieła” opisują go jako istotę niezwykłą: odpowiada za instytucję (zaznaczone przez czytelnika), bez przerwy pracuje, zawsze można się do niego zwrócić z prośbą, zawsze jest gotowy na wezwanie wychowanków. W komunie Makarenki tym nadzwyczajnym człowiekiem był on sam - z jego całodobową czujnością i nieograniczoną władzą nad wychowankami, zwielokrotnianą przez dyżur- 
nych - będących przedłużonym ramieniem władztwa kierownika. Ten zaś sam sobie nadał prawo do osobistego nagradzania i karania wszystkich niżej od niego zhierarchizowanych członków: dodatkową pracą, odebraniem wychodnego, wstrzymaniem kieszonkowego, nałożeniem kary fizycznej lub zarządzeniem izolacji wychowanków (Makarenko 1956: 238; Pyrzyk 2002: 142). Co ciekawe, te fragmenty „Dzieł” czytelnicy uznali za bardzo ważne i podkreślili je kilkakrotnie.

\section{Makarenko w oczach jego wychowanków i czytelników}

Przeglądając zakreślenia sporządzone przez czytelników w pracach A. Makarenki oraz tekstach o nim, można znaleźć fragmenty będące nieomalże apoteozą tego pedagoga. $\mathrm{Na}$ przykład Mikołaj Fere w książce „Mój nauczyciel. A. Makarenko” pisze: „Tak jak Iwan Miczurin tworzył w swych ogrodach nowe gatunki roślin, tak Anton Makarenko w kolektywie dziecięcym stworzył nowego człowieka" (1954: 108). Ukazanie Makarenki jako stwórcy „nowego człowieka” przywołuje nieodparte skojarzenie z Fryderykiem Nietzsche (Rosenthal 2010: 396), gdyż obaj usiłowali w upadające społeczeństwo tchnąć nowego ducha poprzez wykreowanie „,nowego człowieka”: zdolnego przeprowadzić zmiany, oraz przezwyciężyć człowieka będącego „panem dnia dzisiejszego” - zatroskanego o „małe cnoty, małostkową roztropność, pyłkowe względy, to rojenie się mrówcze, tę żałosną błogość, to «szczęście najliczniejszych»" (Nietzsche 2014: 330-331).

Podobnie Makarenko, pisząc o wychowaniu „nowego człowieka” ZSRR ma na myśli młodzież, zdolną obalić wyrosły na podłożu religijnym stary system etyczny i zbudować w tym miejscu etykę proletariatu (Mazur 2008: 94), gdyż - co podkreśla - „kryteria moralne - niemoralne, słuszne - niesłuszne są u nas nowe. (...) (Różnią się tabelą norm etycznych oraz charakterem procesu wychowawczego, który) polega przede wszystkim na ukształtowaniu jego zdolności, a rozwijaniu jego sił, jego twórczej aktywności" (Makarenko 1950: 22). Ale już dalej dodaje, że „dokładne wypełnianie obowiązków jest w naszym społeczeństwie kategorią moralną” (Makarenko 1950: 31), gdzie ów „moralny” wymiar oznacza gotowość podporządkowania się wychowanków komunie oraz woli wychowawcy.

Jak się jednak okazuje, osobliwe rozumienie „moralności” ma także wymiar instrumentalny, gdyż przez Makarenkę jest definiowane jako tak głębokie zinternalizowanie przez wychowanków zasad obowiązujących w komunie, że innego postępowania nawet nie umieliby podjąć, bo ,już tak przywykli” (Makarenko 1956: 433). Instrumentalne podejście do wychowania, jako sposób wytwarzania „nowego człowieka” okazało się atrakcyjne nie tylko dla pedagogów-praktyków, ale też dla teoretyków i na przykład, Anatolij W. Łunaczarski na I Zjeździe Pedologów twierdził, że ,pedologia, gdy ustali, co to takiego dziecko, podług jakich praw ono się rozwija, tym samym objaśni nam najważniejszy proces wytwarzania «nowego człowieka», analogicznie do tego, jak wytwarza się nowe narzędzia” (Mazur 2012: 86). Z analizy hieroglifów na „Dziełach” Makarenki wynika, że „wytwarzanie nowego człowieka” było interesujące także dla kolejnych pokoleń czytających je wychowawców. 
Choć obecnie dorobek Makarenki wydaje się zapomniany, w przeszłości istotnie stanowił przedmiot pedagogicznych dociekań, jednak zważywszy, że książka I. Pyrzyka ukazała się w 2002 roku, nie była to przeszłość nazbyt odległa.

\section{Tłumacz czasu. Zakończenie}

Śledzenie hieroglifów pozostawionych przez czytelników na kartach zgromadzonych w BUG-u „Dzieł” A. Makarenki umożliwia odnalezienie zagadnień, którym nadali oni znaczenie istotnych $\mathrm{w}$ pracy $\mathrm{z}$ wychowankami. $\mathrm{Z}$ analizy wynika, że czytający je szukali:

1) prostych odpowiedzi na pytania: o cele wychowania i skuteczne metody ich osiągania;

2) argumentów utwierdzających wychowawców w posiadanej nad podopiecznymi władzy oraz legitymujących zarządzanie nimi;

3) uzasadnień obowiązku ponoszenia odpowiedzialności za instytucję, i - dla jej dobra - praw do przedmiotowego traktowania wychowanków;

4) wykładni teorii pedagogicznych, modyfikowanych stosownie do własnych potrzeb. Tu jednak trzeba dodać, że postępując zgodnie z nimi przeobrażali się w pewnym sensie w uczniów Makarenki, ponieważ dzięki nim jego idee wciąż były żywe.

Śledzeniu hieroglifów towarzyszyła myśl, że czytający „Dzieła” niejako wchodził w rolę tłumacza Makarenkowskiej pedagogiki, gdyż z prac radzieckiego pedagoga wydobywał:

- nowe sensy, znaczące z jego punktu widzenia, w pracy z współczesnymi wychowankami;

- wybranym zagadnieniom nadawał znaczenie wiodących, inne natomiast uznawał za nieistotne i wykluczał je z refleksji pedagogicznej (Rutkowiak 2009: 33).

Znamienne jest także i to, że analizując zakreślenia dokonane przez czytelników prac Makarenki, ja także weszłam w rolę tłumacza, który w ich translacji wspomagał się metaforą, wykorzystaną jako rodzaj narzędzia przydatnego w czytaniu hieroglifów pozostawionych na „Dziełach”. Towarzyszyła mi przy tym myśl, że ich odkrywanie i przekładanie może wiązać się z ryzykiem nadmiernego uproszczenia myśli pedagoga, spłycenia ich do zaledwie kilku kwestii. Nie było to jednak wyłącznie pochodną obrania określonych założeń metodologicznych prowadzonej analizy, ponieważ w istocie to czytelnicy dokonali ich redukcji, zdeterminowani koniecznością poszukiwania tego, co dyktował im stan świadomości, intelektualna i ideologiczna aura budująca kontekst pracy wychowawczej (Demetrio 2009: 54).

I wreszcie przedstawiona tu próba przetłumaczenia „hieroglifów” uświadomiła bezbronny charakter historii odczytywanej po jakimś czasie (Demetrio 2009: 186-187), bezsilność rekonstruowanych tekstów lub interpretowanych wypowiedzi. Uzmysłowiła również, że sensem tego czytania nie było wskrzeszenie przeszłości; raczej jej roz-jaśnienie niż wy-jaśnienie, bo to ono jest zadaniem thumacza czasu. 


\section{Literatura}

Demetrio D. (2009), Pedagogika pamięci, przeł. A, Skolimowska. Łódź, Wydawnictwo Akademii Humanistyczno-Ekonomicznej w Łodzi.

Fere M. (1954), Mój nauczyciel. A. Makarenko, przeł. N. Drucka. Warszawa, PZWS.

Filipiak E. (2011), Z Wygotskim i Brunerem w tle: Stownik pojęć kluczowych. Bydgoszcz, Wydawnictwo Uniwersytetu Kazimierza Wielkiego.

Foucault M. (2009), Nadzorować i karać. Narodziny więzienia, przeł. T. Komendant. Warszawa, Wydawnictwo Aletheia.

Kosiorek M. (2007), Pedagogika autorytarna. Kraków, Oficyna Wydawnicza Impuls.

Lakoff G., Johnson M. (1988), Metafory w naszym życiu, przeł. T.P. Krzeszowski. Warszawa, PIW.

Makarenko A. (1950), Wybrane prace pedagogiczne, przeł. J.N. Miedyński. Warszawa, Wydawnictwo Nasza Księgarnia.

Makarenko A. (1955), Dzieła t. I, Poemat pedagogiczny, przeł. B. Rafałowska. Warszawa, PZWS.

Makarenko A. (1956), Dzieła t. V. Ogólne zagadnienia teorii pedagogiki. Wychowanie w szkole radzieckiej, przeł. A. Żukowska, J. Wierzbicka, M. Kozakiewicz, B. Milewicz. Warszawa, PZWS.

Mazur M. (2012), „Nowy czlowiek” w Rosji carskiej i Związu Radzieckim do lat 30. XX wieku. „Wrocławskie Studia Wschodnie” 12 (2008). Wydawnictwo Uniwersytetu Wrocławskiego.

Mieszalski S. (1997), O przymusie i dyscyplinie w klasie szkolnej. Warszawa, WSiP.

Nietzsche F. (2014), Tako rzecze Zaratustra, przeł. W. Berent. Wydawnictwo Zysk i S-ka, Poznań.

Passendorfer E. (1968), Procesy egzogeniczne. W: E. Passendorfer (red.), Zarys nauk geologicznych. Warszawa, Wydawnictwo Geologiczne.

Peräkylä A. (2009), Analiza rozmów i tekstów, przeł. A. Figiel. W: N.K. Denzin, Y.S. Lincoln (red.), Metody badań jakościowych, t. 2. Warszawa, Wydawnictwo Naukowe PWN.

Prokopiuk W. (2010), Hermeneutyka jako metodologia rozumienia i interpretacji wiedzy pedagogicznej. W: J. Piekarski, D. Urbaniak-Zając, K.J. Szmidt (red.), Metodologiczne problemy tworzenia wiedzy w pedagogice. Oblicza akademickiej praktyki. Kraków, Oficyna Wydawnicza Impuls.

Pyrzyk I. (2002), Prekursorzy pedagogiki opiekuńczej, Toruń, Wydawnictwo Adam Marszałek.

Richardson L., St. Pierre E.A. (2009), Pisanie jako metoda badawcza, przeł. M. Sałkowska. W: N.K. Denzin, Y.S. Lincoln (red.), Metody badań jakościowych, t. 2. Warszawa, Wydawnictwo Naukowe PWN.

Rosenthal B.G. (2010), New Myth, New World: From Nietzsche to Stalinism. Pennsylvania, Penn State Press.

Rutkowiak J. (2009), Wielość paradygmatów dydaktyki a wspólny mianownik realności życia. Ku pytaniom o przekłady międzyparadygmatyczne. W: L. Hurło, D. Klus-Stańska, M. Łojko (red.), Paradygmaty współczesnej dydaktyki. Kraków, Oficyna Wydawnicza Impuls.

Słownik języka polskiego, http://sjp.pl/hieroglify (dostęp: 9.10.2017).

Śliwerski B. (2015), Współczesne teorie i nurty wychowania. Kraków, Oficyna Wydawnicza Impuls.

Witkowski L. (2013), Przełom dwoistości w pedagogice polskiej. Historia, teoria, krytyka. Kraków, Oficyna Wydawnicza Impuls.

Wygotski L.S. (1971), Problem nauczania i rozwoju umysłowego w wieku szkolnym. W: L.S. Wygotski, Wybrane prace psychologiczne. Warszawa, PWN. 